\title{
MATERIAŁY
}

Mariusz Misztal

DOI: $10.14746 /$ bhw.2017.36.6

Uniwersytet Neofilologii

Uniwersytet Pedagogiczny im. KEN w Krakowie

\section{Teoria i praktyka królewskiego wychowania na przykładzie eksperymentu edukacyjnego wiktoriańskiego księcia Walii}

\begin{abstract}
Theory and practice of royal education exemplified by the Victorian Prince of Wales
For Queen Victoria and Prince Albert the proper education of their eldest son, and the future king of England, was of paramount importance. Their most important advisor in this matter was Baron Stockmar, who believed in strict control of every moment in the boy's life. The article examines available documentary sources dealing with the theory of the prince's education as presented mainly in Queen Victoria's, Prince Albert's and Stockmar's memoirs, as well as the way this theory was translated into practice by the Prince's tutors and teachers. The main documentary sources here are the official reports and private diaries of Lady Lyttelton, Henry Birch and Frederick Gibbs. All in all, to the great disappointment of the Prince's parents, the educational theory promoted by Stockmar proved to be a complete failure.
\end{abstract}

Keywords: royal education, educational experiment, prince of Wales, victorian age

W maju 1853 r. w amerykańskiej „Cambridge Tribune” ukazała się notatka „londyńskiego korespondenta", obrazująca sposób wychowywania najstarszego syna królowej Wiktorii, jedenastoletniego wówczas księcia Walii, Alberta Edwarda ${ }^{1}$. Pewnego dnia, do-

${ }^{1}$ I should like to thank Her Majesty Queen Elizabeth II for granting me access to the Royal Archives in Windsor and for her permission to quote from the documents in the Royal Archives. Dziękuję Jej Wysokości królowej Elżbiecie II za zgodę na kwerendę w Archiwach Królewskich w Windsorze i na cytowanie fragmentów przechowywanych tam dokumentów.

Brak kompleksowego omówienia wychowania i edukacji Alberta Edwarda, ale wszystkie jego biografie, bardziej lub mniej szczegółowo, piszą o jego dzieciństwie, wychowaniu i kształceniu. Najbardziej godne polecenia są dwie pozycje, oparte w dużej mierze na kwerendzie archiwalnej, przełomowa praca Ph. Magnusa, King Edward the Seventh, London 1964, s. 1-23, który jednak nadal nie miał dostępu do wielu materiałów źródłowych, oraz J. Ridley, Bertie. A Life of Edward VII, London 2012, szczególnie s. 15-34; wśród pozostałych biografii wymienić należy G. St. Aubyn, Edward VII. Prince and King, London 1979; S. Weintraub, The 
nosił korespondent, młody książę stał w swoim pokoju w pałacu królewskim w Windsorze przy podzielonym na małe panele oknie, które sięgało od sufitu po podłogę. Miał nauczyć się na pamięć zadany tekst, ale zamiast tego patrzył przez okno na ogród i bębnił palcami w szybę. Jego guwernantka, surowa panna Hillyard (sic)2 ${ }^{2}$, zauważywszy jego zachowanie uprzejmie poprosiła, by wrócił do zadanej lekcji. Młody książę odpowiedział: Nie chcę, na co panna Hillyard odrzekła, W takim razie muszę cię wysłać do kąta, Sir. Nie będę się uczyć, odpowiedział malec zdecydowanie, a w kacie stać nie będę, bo jestem księciem Walii. I mówiąc to, wybił nogą jedną z szybek w oknie. W tej sytuacji, panna Hillyard powiedziała: Sir, albo będziesz się uczyl, albo będę zmuszona wysłać cię do kąta. Nie będę odrzekł książę i wybił nogą drugi panel okna. Guwernantka zadzwoniła na służącego i poprosiła o przekazanie księciu Albertowi, że konieczna jest jego natychmiastowa obecność w pilnej sprawie dotyczącej jego syna. Oddany ojciec przybył od razu i usłyszawszy co się stało, poszedł do swego pokoju i wrócił z Biblią i brzozową rózgą. Postuchaj teraz powiedział do księcia Walii, co święty Apostoł Pawet mówi do ciebie $i$ innych dzieci $w$ twoim położeniu. A następnie zacytował list do Galatów: Jak długo dziedzic jest nieletni, niczym się nie różni od niewolnika, chociaż jest właścicielem wszystkiego. Aż do czasu określonego przez ojca podlega on opiekunom i rzadcom ${ }^{3}$. To prawda, kontynuował książę Albert, że jesteś księciem Walii i jeżeli będziesz się dobrze sprawowat, możesz osiagnać wysoka pozycję społeczna, a nawet po śmierci twojej matki możesz zostać królem Anglii. Ale teraz jesteś tylko małym chłopcem, który musi być postuszny nauczycielom i opiekunom. Poza tym muszę przypomnieć ci inne powiedzenie, madrego Salomona: Nie kocha syna, kto rózgi żałuje, kto kocha go - w pore go karci.

Powiedziawszy to ojciec wziął rózgę i sprawił następcy tronu największego imperium w świecie chrześcijańskim porządne lanie, a następnie wysłał go do kąta, mówiąc: $B e ̨-$ dziesz tam stat $i$ uczyt się, aż panna Hillyard cię zwolni z kary. I nigdy już nie zapominaj, że podlegasz teraz nauczycielom i opiekunom, tak jak w przyszłości będziesz podlegat prawu danemu przez Boga. Korespondent gazety dodaje, że jest to świetny przykład chrześcijańskiego wychowania, który każdy obywatel, który ma dzieci powinien sobie wziąć do serca i naśladowaćs.

Królowa Wiktoria i książę Albert mieli dziewięcioro dzieci. W listopadzie 1841 r., dziewięć miesięcy po ślubie, urodziła się ich pierworodna córka, Victoria, zwana w rodzinie Vicky, która miała być niedościgłym wzorem dla pozostałego rodzeństwa ${ }^{6}$. Kilka miesięcy potem Wiktoria znowu była w ciąży. Ale nie chciała tego drugiego dziecka, bo

Importance of Being Edward. King in Waiting, 1841-1901, London 2000; Ch. Hibbert, Edward VII. The Last Victorian King, London 2007.

2 Powinno być: Hildyard. Panna Hildyard, córka pastora, nazywana była przez dzieci Tilla.

${ }^{3}$ List do Galatów, 4.1, 2. Cyt. za Biblią Tysiąclecia.

${ }^{4}$ Przysłowia, 13.24. Cyt. za Biblią Tysiąclecia.

5 "The Flogging of a Prince", notatka przetłumaczona z "niemieckiej gazety”. „Cambridge Chronicle”, vol. VIII no 21, 21 V 1853, s 3, kolumna a. S. Weintraub, The Importance of Being Edward. King in Waiting 1841-1901, s. 1-2, przytacza tę samą historię na podstawie „New York Tribune”.

${ }^{6}$ Najlepszym opracowaniem dot. Vicky jest H. Pakula, An Uncommon Woman. The Empress Frederick. Daughter of Queen Victoria, Wife of the Crown Prince of Prussia, Mother of Kaiser Wilhelm, London 1995. 
zdecydowanie uważa kobiety, które ciągle są w ciąży, za odpychajace; przypominaja raczej królice albo świnki morskie ${ }^{7}$. W listopadzie 1841 przyszedł na świat pierwszy syn Wiktorii i Alberta ${ }^{8}$, Albert Edward, zwany w rodzinie Bertie ${ }^{9}$, następca tronu z tradycyjnym tytułem księcia Walii ${ }^{10}$.

W roku 1857 rodzina królewska liczyła już 11 osób ${ }^{11}$. Narodziny księcia Walii wywołały ogólnonarodową euforię, ale kiedy z prawie każdym rokiem przybywało królewskich dzieci, a ekonomiści zaczęli wygłaszać publiczne prelekcje na temat zagrożenia przeludnieniem, coraz częściej krytykowano wzrost liczby królewskich zjadaczy podat$k o ́ w^{12}$. Wiktoria była bardzo zaintrygowana swoimi najstarszymi pociechami i pisała, że chociaż sa często źródłem wielu trosk i problemów, dzieci sa wielkim błogosławieństwem $i$ rozweselaja $i$ rozjaśniają nasze życie ${ }^{13}$. Ale w miarę jak zwiększała się ich gromada, stawała się w stosunku do nich coraz bardziej niecierpliwa i spędzała z nimi coraz mniej czasu, w końcu traktując ich wręcz jako rywali w walce o uczucia męża. Lata później zwierzała się Vicky, że często miałam wam dzieci za złe, że wszędzie było was petno, kiedy marzyłam, aby pobyć chwilę sam na sam z najdroższym Papa! To były zawsze moje najszczęśliwsze chwile! ${ }^{14} \mathrm{Z}$ czasem nie fascynowała się już ich rozwojem i dorastaniem, ale ubolewała nad kultem uwielbienia dzieci i przestrzegała swą starszą córkę przed okazywaniem im zbyt wielkiego uczucia i stawania się ich niewolnica ${ }^{15}$.

Tak jak i w innych zamożnych domach, dzieci przeważnie przebywały cały dzień w osobnych pokojach pod opieką nianiek, a potem guwernantek, wspólnie bawiąc się, ucząc i spożywając posiłki. Jednak codziennie wieczorem wszystkie po kolei składały matce wizytę. Przyglądała im się bacznie, wypytywała o zajęcia dnia, ganiła złe zachowanie lub brak postępów w nauce. Albert natomiast, przynajmniej do czasu aż całkowicie pochłonęła go praca nad niekończącymi się projektami i sprawami państwowymi, poświęcał swoim dzieciom więcej czasu niż większość wiktoriańskich ojców.

W 1847 r. rodzice opracowali memoriał dotyczący sposobu edukacji dzieci, która miała być oparta na przekonaniu Wiktorii, że dzieci powinno się wychowywać w jak najprostszy sposób" i że po lekcjach powinny spędzać tak wiele czasu jak tylko możliwe

\footnotetext{
${ }^{7}$ Queen Victoria to the Crown Princess, Victoria, 15 VI 1859, Dearest Child: Letters Between Queen Victoria and the Princess Royal,1858-61, oprac. R. Fulford, Londyn 1964, s. 195.

${ }^{8}$ Queen Victoria's Journal (Princess Beatrice's copies), 2 XII 1848. On line www.queenvictoriasjournals. org [Dostęp: 1210 2015]

9 Wiktoria to króla Leopolda, 6 VI 1843, Letters of Queen Victoria: A Selection from Her Majesty's Correspondence, ed. Arthur Christopher Benson and Viscount Esher, 3 vols., London 1907, t. 1, s. 602.

${ }^{10}$ Queen Victoria's Journal, 10 XII 1841.

${ }^{11}$ W 1843 r. urodziła się Alice, a następnie Alfred (1844), Helena (1846), Louise (1848), Arthur (1850), Leopold (1853) i Beatrice (1857).

12 Por. D. Thompson, Queen Victoria. A Woman on The Throne, London 2001, s. 44.

13 Queen Victoria's Journals, 10 II 1852.

${ }^{14}$ Queen Victoria to the Crown Princess, Victoria, 2 III 1958, Dearest Child..., s. 68.

1522 VI 1858, Ibidem, s. 118. Na temat podejścia królowej Wiktorii do macierzyństwa zob. M. Misztal, Królowej Wiktorii spojrzenie na macierzyństwo, w: Człowiek w teatrze świata, red. B. Popiołek, Kraków 2010, s. $53-68$.
} 
ze swoimi rodzicami, ucząc się pokładać w nich swe zaufanie we wszystkich sprawach ${ }^{16}$. Wszelkie problemy, nagrody i kary, które w przypadku zarówno chłopców, jak i dziewcząt polegały najczęściej na staniu w kącie z zawiązanymi do tyłu rękami, miały być szczegółowo ustalane z królową ${ }^{17}$. Książę Albert nie stronił jednak od kar cielesnych, nawet w przypadku dziewcząt i np. czteroletnia Alice otrzymała porządne lanie za kłamanie i wrzaski ${ }^{18}$.

Dzieci były podzielone na klasy. Głównym celem pierwszej, do szóstego roku życia, był rozwój fizyczny, wychowywanie i wpajanie posłuszeństwa, ale uczono je również angielskiego, francuskiego, niemieckiego i elementów religii. Potem przechodziły do klasy drugiej, gdzie pod okiem guwernantki, miały rozwijać „siłę charakteru”. Po ukończeniu siedmiu lat, w trzeciej klasie, książęta dostawali własnego tutora i służącego, a księżniczki służącą i guwernantkę, która instruowała je w manierach towarzyskich aż do ich zamążpójścia. Uczenie dobrych manier miało być głównym celem edukacji dziewcząt, ale miały również nauczycieli sztuki, muzyki i tańca. W czwartej klasie, trzynastoletni książęta mieli być zaznajamiani z życiem $i$ światem. Niedziela miała być dniem zabawy i odpoczynku, i Wiktoria odrzucała stanowczo opinie, że nie godzi się w niedzielę grać w krykieta czy zajmować takimi niewinnymi rozrywkami, jak teatr amatorski, tańce czy strzelanie ${ }^{19}$.

Ważne miejsce w wychowywaniu dzieci miały rzeczy praktyczne, dlatego w $1853 \mathrm{r}$. Albert zaplanował w Osborne i nadzorował budowę Chatki Szwajcarskiej. Wnętrze było dostosowane do wzrostu dzieci i obejmowało w pełni wyposażoną kuchnię i piec. Tu książęta mogli uczyć się stolarstwa i ogrodnictwa, a księżniczki nie tylko ogrodnictwa, ale też gotowania i prowadzenia domu. Talerze miniaturowych herbacianych, obiadowych i deserowych serwisów ozdobiono inskrypcją Kto nie marnuje, temu nie brakuje. W jednym z pomieszczeń zorganizowano sklep spożywczy dla lalek, Spratt, sklep spożywczy Jej Wysokości, gdzie dzieci mogły poznawać ceny różnych produktów. Kamienie, skamieliny i rośliny zbierane pod okiem Alberta wystawiane były w małym muzeum historii naturalnej na pięterku. W ogrodzie obok chatki, każdemu dziecku przydzielono osobne grządki i narzędzia ogrodnicze, ze szpadlami, motykami i taczkami, a każdą godzinę przepracowaną w ogrodzie wynagradzano niewielką zapłatą. Nieopodal w minia-

\footnotetext{
${ }^{16}$ Royal Archives, Windsor Castle (cytowane dalej jako RA) VIC/MAIN/M/12/55, Memorandum by Queen Victoria and Prince Albert, 3 I 1847.

17 "We have taken a drive... the Princess Alice having been sadly naughty and disobedient all the way; and ended by arriving in the most stunning roar. I thought the case very grave, and that I should obey His Royal Hihness's instructions best, by administering a real punishment, by whipping". RA VIC/MAIN/M/13/87, Lady Lyttelton to the Queen, 18 VIII 1847.

18 Ibidem. Por. opinię Lady Campbell, że „nie ma sensu ganić dzieci, lepiej od razu spuścić im lanie”. Queen Victoria's Journal, 3 VIII 1838, oraz opinię Lorda Melbourne, że „kara chłosty” zrobiła mu wiele dobrego i żałuje, że w Eton nie karano go w ten sposób częściej. Ibidem, 15 X 1838, zob. też Ibidem, 1 X 1838. Por. też L. G. Mitchell, Lord Melbourne, 1779-1848, Oxford 1997, s. 213-215.

${ }^{19}$ RA VIC/MAIN/M/12/55, Memorandum by Queen Victoria and Prince Albert, 6 I 1847.
} 
turowym ziemnym forcie, z prawdziwymi strzelającymi działami z mosiądzu, książęta ćwiczyli taktykę rozgrywania bitew ${ }^{20}$.

Najwięcej troski przysparzał rodzicom najstarszy syn, Bertie. Tak jak w przypadku Vicky, zaraz po urodzeniu Bertie został oddany mamce, niejakiej Mary Ann Brough ${ }^{21}$, która jednak została zwolniona po ośmiu miesiącach, bo była ponura, zrzędliwa $i$ głu$p_{i a^{22}}$. W czasie kiedy powszechnie wierzono, że wraz z mlekiem mamki mogą przejść na dziecko jej cechy charakteru, wady i zalety ${ }^{23}$, można sobie jedynie wyobrazić przerażenie Wiktorii, kiedy w 1854 r. dowiedziała się, że Brough zabiła w napadzie szału swoich sześcioro dzieci ${ }^{24}$. Sama Wiktoria była karmiona przez matkę, która zwierzała się, że zbyt uwielbia maleństwo, aby pozwolić karmić ją jakiejś obcej kobiecie i dodawała, że matki, które rezygnują z karmienia omija wiele prawdziwej joie de vivre[radości życia] ${ }^{25}$. Pomimo to, królowa odczuwała do karmienia piersią ogromna awersję, uznając je za część tej poniżajacej $i$ zwierzęcej strony macierzyństwa ${ }^{26}$.

Królowa miała niezmiernie wysokie oczekiwania co do swojego następcy. Wielką nadzieją Wiktorii było to, że Bertie, przyszły król, będzie przypominał swego anielskiego kochanego ojca. Po urodzeniu synka pisała do wuja Leopolda, którego uważała za drugiego ojca ${ }^{27}$ : Ciekawa jestem, kogo będzie przypominat nasz mały chłopczyk. Z pewnościa rozumiesz, tak jak z pewnościa wszyscy, jak żarliwe sa moje modlitwy by zobaczyć, $\dot{z} e$ [Bertie] przypomina swego anielskiego kochanego Ojca pod każdym, każdym względem, tak ciałem jak $i$ umysłem ${ }^{28}$. Królowa nazywała synka, „chłopczykiem” i jeszcze półtora roku po jego urodzinach pisała: nie uważam, że jest już godny by go nazywać

\footnotetext{
${ }^{20}$ N. Tucker, Swiss Cottage, Osborne House, Isle of Wight, „History Today” vol. 40, no. 9 (September 1990), s. 62-63; S. Weintraub, The Importance of Being Edward, s. 9-10.

${ }^{21}$ RA VIC/MAIN/Y/198/140, Queen Victoria to Leopold, king of Belgians, 14 XII 1841; Queen Victoria's Journal, 25 I 1842.

${ }^{22}$ Queen Victoria's Journal, 16 VII 1842. J. Ridley, Bertie, s. 15, pisze o Brough, ale nie wspomina o jej zwolnieniu.

${ }^{23}$ Por. „Razem z mlekiem mamki muszą się także wszystkie namiętności i skłonności mamki na dziecko przenieść, tj. dziecko wsało z mlekiem mamki skłonność do kłamstwa, do gniewu, do lenistwa itp.”. F. E. Bilz, Nowe lecznictwo przyrodne, Lipsk 1903, s. 378, cyt. za Monika Nawrot-Borowska, Mamki - najemne karmicielki w świetle literatury poradnikowej z drugiej połowy XIX i początku XX wieku, „Biuletyn Historii Wychowania" 31 (2014), s. 85-112.

${ }^{24}$ Queen Victoria's Journal, 13 VI 1854; RA VIC/MAIN/Y/99/23, Queen Victoria to Leopold, king of Belgians, 13 VI 1854. Trial of a Woman for the Murder of Her Six Children - Plea of Insanity, "The New York Times" 25 VIII 1854, Murder of six children by their mother, "The Sidney Morning Herald” 12 IX 1954, s. 2, kolumna a; "Freeman's Journal" 16 IX 1854, s. 4, kolumna a. Brough zmarła w szpitalu dla obłąkanych W $1861 \mathrm{r}$.

${ }^{25}$ RA VIC/MAIN/M/3/6, The Duchess of Kent to the Dowager Duchess of Coburg, 22 VI 1819; Lynne Vallone, Becoming Victoria, London 2001, s. 4-5.

${ }^{26}$ Queen Victoria to the Crown Princess, Victoria, 15 VI 1858, Dearest Child, s. 115. Kiedy jej druga córka, Alice, zdecydowała się sama karmić dzieci piersią, rozzłoszczona królowa nazwała jej imieniem jedną z mlecznych krów w Windsorze. Zob. M. Misztal, Królowej Wiktorii spojrzenie na macierzyństwo.

27 ,il mio secondo padre” Journals of Queen Victoria, 16 IX 1836.

${ }^{28}$ Queen Victoria to Leopold, king of Belgians, 7 XII 1841, Letters, 1: 460. Por. Queen Victoria's Journal, 12 XI 1841, 25 I 1842.
} 
Albert $^{29}$. Niestety, to marzenie królowej nigdy się nie spełniło i wszyscy w rodzinie nazywali go zawsze Bertie.

W trosce o przyszłość Bertiego, rodzice drobiazgowo dyskutowali jego fizyczny, intelektualny, a szczególnie moralny trening. Bertie był miłym dzieckiem, ale wyjątkowo powolnym i niechętnym do współpracy uczniem. Wiktoria przekonywała samą siebie, że jest „dobrym” chłopcem i wcale „nie brakuje mu inteligencji”, ale jest „niepewny i nie wierzy w siebie", dlatego za radą męża świadomie dystansowała się emocjonalnie od syna, zapewne w przekonaniu, że uwolnienie od nazbyt silnych więzi z matką przyczyni się do rozwoju jego niezależności i innych cech przywódczych. Ale postronni obserwatorzy widzieli to inaczej i wszechwiedzący Charles Greville, powtarzał krążące plotki, że królowa nie bardzo lubi to dziecko ${ }^{30}$. Pierwsze siedem lat życia Bertiego upłynęło w stosunkowo swobodnej atmosferze, pozbawionej rygorystycznej edukacji, której miał był wkrótce ofiarą.

Wykształcenie przyszłego władcy była dla rodziców sprawą niezmiernie ważną. Od tego miało zależeć, czy Bertie będzie kontynuował program moralnej odnowy monarchii zapoczątkowanej przez rodziców, czy będzie przypominał swoich rozpustnych Hanowerskich wujów. Z czasem matka zaczęła zauważać również pozytywne cechy syna. W jego dziewiąte urodziny pisała w dzienniku, że jest w nim wiele dobrego. Jest taki czuły, bardzo prawdomówny i prostolinijny ${ }^{31}$. Ale to nie wystarczało do godnego wypełniania jego przyszłej roli. Istniało tylko jedno panaceum, w które wierzyli głęboko Wiktorianie - edukacja.

Książę Albert zdawał sobie dobrze sprawę, że rola i wpływy monarchy zmieniły się w dużym stopniu od czasu panowania poprzedników Wiktorii, że obecnie monarcha panuje, ale nie rządzi, i że od 1830 r. władza wykonawcza znajduje się w rękach rządu ${ }^{32}$, a rola monarchy - jak to trafnie sformułował Walter Bagehot - ogranicza się do trzech praw: do udzielania rad, do zachęcania oraz do formułowania ostrzeżeń. Monarcha jest symbolem 'godności', jednocząc lojalność i posłuszeństwo poddanych do państwa oraz umacniając pozycję rządu potęgą stojącej za nią religii, a jako głowa społeczeństwa stanowi wzorzec moralności ${ }^{33}$. Dlatego Albert uważał, że wzmacnianie wpływów monarchy jest możliwe jedynie dzięki osobistemu charakterowi władcy ${ }^{34}$.

Albert poprosił o opinię i radę w sprawie kształcenia następcy tronu ważne i wpływowe osobistości, jak np. przyszłego wielokrotnego premiera Williama Ewarta Gladstone'a, znanego wcześniej ze swoich studiów nad Homerem, wpływowego historyka Tho-

${ }^{29}$ RA VIC/MAIN/Y/198/181, Queen Victoria to Leopold, king of Belgians, 14 VII 1843.

${ }^{30}$ Greville Diary, 22 I 1848.

31 Queen Victoria's Journal, 9 XI 1850.

32 Christian F. Stockmar to Prince Albert, 27 XII 1845, Theodore Martin, Life of H.R.H. the Prince Consort, 5 vols., London 1875-1880, t. 1, s. 314.

33 W. Bagehot, The English Constitution, London 1867.

${ }^{34}$ RA VIC/MAIN/Y/148/1, Prince Albert to Christian F. Stockmar, 6 I 1846, Martin, Life, t. 1, s. 316. 
masa B. Macaulaya, czy biskupa Oksfordu, Samuela Wilberforce'a, który za nadrzędny cel uznał wyedukowanie księcia Walii na najbardziej doskonałego człowieka ${ }^{35}$.

Szeroko omawianym głosem w dyskusji na temat wykształcenia Bertiego był zadedykowany królowej anonimowy pamflet, który ukazał się w 1843 r. pod tytułem Kto powinien edukować księcia Walii?. Autor sugerował, że nie mogą to być mężowie stanu ani politycy, którzy oczywiście zabiegają o stanowiska ministerialne, ani ludzie Kościoła, bo ci marzą o biskupich zaszczytach, poza tym powierzanie kształcenia dzieci klerykom jest reliktem barbarzyństwa (s. 10-12). Tutor powinien być bezpartyjny i oddany prawdzie, mieć zamiłowanie do nauki i potrafić uzmysłowić księciu, że nie ma królewskiej drogi do wiedzy. Pamflet powołuje się ciągle na takie autorytety, jak: Platon, Sokrates, Fenelon, Montaigne, czy Rousseau, a jeżeli chodzi o sposób nauczania, sugeruje, że książę nie powinien niczego uczyć się na pamięć, ale zdobywać wiedzę przez myślenie, poszukiwanie i rozwiązywanie problemów za pomocą wiązania ze sobą faktów, porównywania i wyciągania wniosków. Oprócz rozwijania umysłu książę powinien również rozwijać swoje ciało, przez sporty i jazdę konną. Podczas długich spacerów po lesie i po łąkach powinien poznawać naturę, podczas wypraw incognito do miast i wsi, powinien poznawać swoich poddanych. Książę musi też zdać sobie sprawę z tego, że król Anglii jest urzędnikiem, poważanym i sowicie opłacanym przez ciężko pracujących poddanych, by czuwał nad utrzymaniem powszechnego porządku, wolności i bezpieczeństwa, a nie by zapewnić mu zmysłowe przyjemności i wystawne życie. Na koniec, autor przyznaje, że zdaje sobie sprawę, że takie wykształcenie księcia Walii jest jedynie jego marzeniem, które pewnie zastanie odrzucone $\mathrm{z}$ niesmakiem przez decydentów.

Również wpływowy satyryczny „Punch” zabrał głos w dyskusji nad wykształceniem księcia. W artykule zatytułowanym Kształcenie królewskich dzieci opisuje, że ponad murem otaczającym Pałac Buckingham, gdzie mieszkała królewska rodzina, zauważono, że pojawiła się huśtawka. Dzięki temu wspaniałemu pomysłowi dzieci królewskie od małego będą miały wpajaną prawdę, że nawet książęta są raz na dole a raz na górze, raz na wozie a raz pod wozem, że czasami posuwamy się do przodu, ale czasami musimy się cofnąć, a są to prawdy na zrozumienie których nigdy nie jest zbyt wcześnie ${ }^{36}$.

Ze wszystkich opinii sławiących możliwości edukacji wyłamywał się leciwy już Lord Melbourne, który ostrzegał, że nawet bardzo rygorystyczna edukacja rzadko osiąga tak wiele jak się po niej oczekuje, może kształtować i ukierunkować charakter, ale rzadko go zmienia $^{37}$. Przeciwstawny punkt widzenia reprezentował baron Christian Stockmar, totumfacki wuja Alberta i Wiktorii, Leopolda, od 1831 r. króla Belgów, który od ich ślubu pełnił nieoficjalną funkcję opiekuna politycznego i który został najbardziej wpływowym doradcą w procesie opracowywania zasad i celów edukacji księcia Waliii ${ }^{38}$.

${ }^{35}$ RA VIC/MAIN/M/12/46 (enclosure to 45, kopia: RA VIC/MAIN/Y/184/12, Memorandum Bishop of Oxford, Samuel Wilberforce.

${ }^{36}$ Education of the Royal Infants "Punch, or the London Charivari" IV (1843), s. 232.

37 Viscount Melbourne to Queen Victoria, 1 XII 1841, Letters, 1: 458

${ }^{38} \mathrm{Ch}$. Grey, The Early Years of His Royal Highness The Prince Consort. Compiled under the Direction of Her Majesty the Queen, New York 1867, s. 160, zawiera następującą opinię królowej o Stockmarze: „Królowa 
W latach 1842-1848 Stockmar przygotował serię memoriałów, które podkreślały konieczność prawdziwie moralnego i prawdziwie angielskiego wykształcenia. Stockmar uznał, że konieczny jest system, który zapewni, że Bertie jako przyszły „zarządca kraju” stanie się skarbnica wszelakich moralnych i intelektualnych cnót, które będa kraj scalały i pod których przewodnictwem będzie się on posuwat naprzód na wielkiej drodze cywili$z a c j i^{39}$. Tradycja protestancka uczyła, że aby w dorosłym życiu książęta nie dawali posłuchu otaczającym im pochlebcom, należy od najmłodszych lat rozwijać w nich bezwzględną moralność, zamiłowanie do ciężkiej pracy i poczucie obowiązku. System edukacji Bertiego opracowany przez Stockmara był typowy dla niemieckiego modelu kształcenia książąt w XIX w..$^{40}$ i przypominał sposób wychowania i edukacji księcia Alberta $^{41}$.

Założeniem systemu proponowanego przez Stockmara było, że dziecko rodzi się z naturalnymi skłonnościami do dobra i zła, a zadaniem edukacji jest rozwijanie i wzmacnianie tych pierwszych, a poskramianie i osłabianie tych drugich, i nigdy nie jest za wcześnie by rozpocząć dobra edukację $e^{42}$. Powtarzał tu opinię Johna Locke'a, że zaniedbanie początków jest podstawowym błędem rodziców. Stockmar, podobnie jak Locke, uważał, że edukacja polega na organizowaniu doświadczenia. $W$ dziewięciu dziesiatych sa tym, czym są dzięki edukacji, pisał John Locke i argumentował, że doświadczenia edukacyjne powinny być fizyczne, umysłowe i duchowe - zdrowy duch $w$ zdrowym ciele $^{43}$.

Stockmar pisze, że głównym zadaniem wychowawcy jest regulowanie naturalnych instynktów dziecka i dbanie o czystość umysłu. A zadanie rodziców następcy tronu jest o wiele trudniejsze od innych rodziców, bo ich dzieci muszą nie tylko być osobami o wysokich wartościach moralnych, ale również otrzymać przygotowanie do wywiązywania się z sukcesem z ich przyszłych obowiązków jako monarchów ${ }^{44}$. Stockmar przypomina o błędach popełnionych przez poprzednich władców, szczególnie Jerzego III, który nie

wspominając z wdzięcznością i sympatią przyjaciela z początkowych lat małżeństwa, nigdy nie zapomni o pomocy której Baron udzielił młodej parze... w ukierunkowaniu edukacji ich dzieci”. Nt. wpływów Stockmara zob. E. A. Stockmar, Denkwürdigkeiten aus den Papieren des Freiherrn Christian Friedrich v. Stockmar, Braunschweig 1872; P. Crabites, Victoria's Guardian Angel: A Study of Baron Stockmar, London 1937.

${ }^{39}$ RA VIC/MAIN/M/12/44, Ch. F. Stockmar's Opinion on the Question - Should the Instructor of the Prince of Wales be a Clergyman, or a Layman?, 30 VII 1846.

40 J. Meyer, E'Education des Princes en Europe du XVe au XIXe Siecle, Perrin 2004, s. 210-14.

${ }^{41}$ Zob. M. Misztal, Królowa Wiktoria, Ossolineum 2002, s. 89-91; Charles Grey, The Early Years of the prince Consort, London 1869; S. Weintraub, Albert. Uncrowned King, London 1997, s. 39-65.

42 RA VIC/MAIN/M/12/14, Memorandum by Ch. F. Stockmar, 6 III 1842.

43 "A sound mind in a sound body". J. Locke, Some Thoughts Concerning Education. Vol. XXXVII, Part 1. The Harvard Classics. New York: P.F. Collier \& Son, 1909-14; Bartleby.com, 2001. www.bartleby.com/37/1/, par. 1. Locke nawiązuje tu do łacińskiej sentencji mens sana in corpore sano użytej przez Juwenalisa w Satyrze $X$ (10.356). Zob. też A. Raniszewska-Wyrwa, Johna Locke'a koncepcja wychowania moralnego, „Biuletyn Historii Wychowania” 31 (2014), s. 161-175.

${ }^{44}$ RA VIC/MAIN/M/12/14 Memorandum by Ch. F. Stockmar, 6 III 1842. 
zdołał zaszczepić w umysłach swoich synów ,zasad prawdy i moralności”, co doprowadziło do rozwiązłości i upadku moralnego monarchiii ${ }^{45}$.

Równie ważny, według Stockmara, był wybór na tutorów księcia ludzi dobrych i o nieposzlakowanej opinii, godnych absolutnego zaufania. Uważał, że edukacja człowieka rozpoczyna się od pierwszego dnia jego życia i najlepszym prezentem dla oczekiwanego dziecka jest szczęśliwy wybór [opiekunki] ${ }^{46}$. Rodzice muszą mieć kompletne zaufanie do opiekunki. W przypadku dzieci królewskich, osoba odpowiedzialna za ich wychowanie musi też mieć wyszukane maniery, doświadczenie i powinna być osobą z towarzystwa, aby tym łatwiej zyskać pełny posłuch u personelu ${ }^{47}$. Stockmar miał swoją kandydatkę. Była nią Lady Sarah Lyttelton, która od wstąpienia Wiktorii na tron była damą dworu. Jej podstawowym zadaniem był nadzór nad damami do towarzystwa, z którego wywiązywała się doskonale. Przyjazna, choć pełna „odpowiedniej powagi” matrony, była powszechnie lubiana na dworze. Na prośbę Wiktorii Lady Lyttelton zgodziła się objąć nadzór na żłobkiem ${ }^{48}$.

Lady Lyttelton, która przebywała $\mathrm{z}$ dziećmi większość dnia, potrafiła $\mathrm{w}$ bardziej obiektywny niż inni sposób ocenić charakter Bertiego ${ }^{49}$. Nie był łatwym dzieckiem, był marudny i często miewał napady złości i wybuchy złego humoru. Kiedy kazano mu robić to, na co nie miał ochoty, zaczynał krzyczeć i wierzgać nogami lub tupać ze złością, rzucać wszystkim dookoła, aż do utraty tchu. O dwuletnim Bertim Lady Lyttelton pisała, że jest tak niegrzeczny jak większość dzieci, ale nie bardziej, i myślę, że zapowiada się dobrze pod względem usposobienia i intelektu ${ }^{50}$. Rok później oceniała, że Bertie nie wysławia się tak jasno jak jego siostra [Vicky], i ma raczej dziecinny sposób mówienia i chociaż rozumie trochę francuskiego, ogólnie jest opóźniony w języku, bardzo inteligentny $i$ wielkoduszny, ma łagodny charakter, z okazjonalnymi jedynie napadami pasji i tupaniem $^{51}$. Z czasem przykłady buntu stawały się coraz częstsze, Bertie odmawiał

\footnotetext{
45 Nt. kształcenia dzieci Jerzego III zob. „The Education of the Hanoverian Kings in the Age of Reason: From George I to William IV", w: P. Gordon, D. Lawton, Royal Education. Past, Present and Future, revised edn, London: Frank Cass, 2003, s. 91-132. Z oczywistych względów, Stockmar przemilcza skandale związane z rodzicami Alberta: matka, która miała już dość niekończących się romansów rozpustnego męża, sama zaczęła szukać pociechy w ramionach innego mężczyzny i ostatecznie zdecydowała się opuścić Koburg i zamieszkać ze swoim kochankiem, którego po otrzymaniu rozwodu poślubiła. Pojawiały się też spekulacje, że Albert nie był synem księcia Ernesta, ale, że jego prawdziwym ojcem był baron von Meyern, Żyd z pochodzenia, szambelan na dworze w Koburgu. Zob. S. Weintraub, Albert. Uncrowned King, s. 20-36.

${ }^{46}$ RA VIC/MAIN/M/12/14 Memorandum by Ch. F. Stockmar, 6 III 1842; RA VIC/MAIN/Y/153/9 Ch. F. Stockmar to Prince Albert, 1 X 1840; P. Crabites, op. cit., s. 125.

${ }^{47}$ RA VIC/MAIN/M/12/16, The Queen to Melbourne 24 III 1942; RA VIC/MAIN/M/12/17, Lord Melbourne to the Queen, 25 III 1842.

${ }^{48}$ Queen Victoria's Journal, 6 IV 1842.

49 Ibidem.

${ }^{50}$ RA VIC/MAIN/M/13/46, Lady Lyttelton to Queen Victoria, 29 IX 1843.

${ }^{51}$ Lady Lyttelton to Queen Victoria, 16 II 1844, Lord Esher, The Influence of King Edward, London: John Murray 1915, s. 6.
} 
uczenia się, rozrzucał książki i chował się pod stołem. Zaczął się też jąkać, a naśmiewanie się Vicky z jego sposobu mówienia, doprowadzało go to do furii ${ }^{52}$.

Lady Lyttleton potrafiła pogodzić matczyna czułość ze zdrowym rozsądkiem ${ }^{53}$. Gdy Bertie miał dwa lata, pisała do Wiktorii, że jego ,największą zbrodnią” było wyrzucanie przez okno zamku w Windsorze żołnierzyków, ale mało prawdopodobne by to zachowanie miało stworzyć niebezpieczny precedens na jego dalsze życie ${ }^{54}$. Z rzadka jedynie sięgała po zalecane przez Alberta i Wiktorię kary, szczególnie cielesne. Matka pięciorga dzieci, doradzając swojej synowej jak wychowywać córeczkę, pisała:

Nie sądzę, żeby wybuchy płaczu w jej wieku oznaczały paskudny charakter. A co do tego jak je powstrzymywać, myślę że najlepiej nie zwracać na nie uwagi. Przyznam, że jestem przeciwko karom; szybko się wyczerpują, i nigdy nie wiadomo czy dziecko rozumie, że są następstwem złego zachowania ${ }^{55}$.

Lady Lyttleton dała Bertiemu podstawy języków obcych. Z niemieckim, używanym często na dworze, nie miał problemu, bo w żłobku dzieci mówiły do siebie po niemiecku i w wieku pięciu lat czytał książki w tym języku ${ }^{56}$. Lady Lyttelton zanotowała, że pierwsze wypowiedziane przez niego zdanie było po angielsku ${ }^{57}$, ale mimo że sławny aktor George Bartly został jego nauczycielem angielskiej dykcji ${ }^{58}$, jeszcze lata później zauważano, że jego angielski brzmi bardzo obco ${ }^{59}$. Nie ma zachowanych nagrań jego głosu, ale według powszechnej opinii do końca życia, nawet w czasie publicznych wystąpień, wymawiał „r” w niemiecki, guturalny, sposób.

Nieszczęściem Bertiego było to, że zawsze był porównywany przez rodziców do swojej starszej siostry, która była nieprzeciętnie inteligentna i bystra. Lady Lyttelton przyznawała, że Vicky jest niezwykle delikatnym, wrażliwym i uczuciowym dzieckiem, o raczej drażliwym usposobieniu, ale zauważała też, że jest wystarczająco inteligentna i sprytna, żeby swoje fochy zachować dla opiekunki, a w obecności matki zachowywać się wzorowo ${ }^{60}$. Toteż zapiski i listy Wiktorii są pełne pochwał dla jej „ujmującego" sposobu bycia oraz przykładów inteligencji, taktu i trafnych powiedzeń ${ }^{61}$.

${ }^{52}$ RA VIC/MAIN/M/13/68, 74, Lady Lyttelton's Journal, 24 VIII 1845, 3 IX 1845

${ }^{53}$ Keith Middlemas, Edward VII, London: Weidenfeld and Nicolson, 1972, s. 17.

${ }^{54}$ RA VIC/MAIN/M/13/45, Lady Lyttelton to Queen Victoria, H. Pakula, op. cit., s. 18.

${ }_{55}$ Correspondence of Sarah Spencer, Lady Lyttelton, 1787-1870, ed. Mrs. Hugh Wyndham, London 1912, s. 327 .

56 S. B. Bunsen, King Edward VII, Macmillan 1925, 1:17.

${ }^{57}$ RA VIC/MAIN/M/13/51, Lady Lyttelton to Queen Victoria, 11 IX 1844

58 Queen Victoria's Journal, 2 VIII 1855.

59 RA VIC/MAIN/Z/442/43, Frederick W. Gibbs to Prince Albert, 14 VIII 1857.

${ }^{60}$ Lady Lyttelton to Queen Victoria, 5 II, 5 IX 1842, Lady Lyttelton's Correspondence, 1787-1870, ed. Mrs Hugh Wyndham, London 1912, s. 327-9.

${ }^{61}$ Zob. H. Pakula, op. cit., s. 15-19. Jednak lata później królowa pisała do swej dorosłej córki, że ,,nigdy nie spotkała bardziej nieusłuchanej i krnąbrnej dziewczyny", a sposób i ton, w jaki Vicky zwracała się do matki nawet przy obcych, ,szokował” wszystkich. 28 VII 1858, Dearest Child, s. 124-5. 
Lady Lyttelton widziała jednak, że przebiegła Vicky nie stroni od kłamstwa, jeżeli tylko widzi w tym swój interes, natomiast Bertie zawsze mówił prawdę. Był czarującym dzieckiem, miał naturalny dar do okazywania sympatii i bardzo starał się, by zadowolić innych, chociaż nie przychodziło mu to łatwo ${ }^{62}$. Lady Lyttelton uważała też, że Bertie więcej się uczy, obserwując innych niż czytając książki. Niestety, rodzice nie zauważali pozytywnych cech Bertiego i wychwalając pod niebiosa cnoty i osiągnięcia Vicky, nieustannie krytykowali wady i braki Bertiego, którego Wiktoria wkrótce uznała za „opóźnionego w rozwoju"63.

Zaniepokojeni rozwojem synka rodzice kilkakrotnie wzywali na konsultację znanych frenologów ${ }^{64}$, Andrew Combe ${ }^{65}$ i jego brata George'a Combe ${ }^{66}$, którzy na podstawie kształtu czaszki chłopca mieli określić, jakie ma talenty i ułomności, i doradzić jak z nim postępować. Zbadawszy dokładnie czaszkę cztero i półletniego Bertiego, George Combe, zwrócił uwagę na szczególne cechy jego usposobienia i mózgu i ocenił, że marna jakość mózgu oznacza, że książę będzie nadpobudliwy, podatny na gwałtowne wybuchy złości, uparty i nieustępliwy, ale nie będą to zamierzone działania, a jedynie skutek fizjologicznej struktury jego mózgu. Organy mózgu odpowiedzialne za ostentację, destruktywność, poczucie własnej wartości, zadziorność i potrzebę aprobaty przez innych są duże. Organy odpowiedzialne za intelekt są jedynie średnio rozwinięte”. Rezultatem będzie „silna wola, czasem upór", a jego poczucie własnej wartości jest tak wielkie, że będzie niezwykle wyczulony na wszystko, co ma na niego wpływ.

W konkluzji dr Combe wnioskował, że nie należy traktować księcia ,jak normalnego dziecka", bo naleganie na ścisłe przestrzeganie reguł i zmuszanie go do wielogodzinnej nauki mogą być dla niego niebezpieczne. Raczej, należy pozwalać mu często na odpoczynek, zachęcać - ale nie zmuszać - do uczenia się, a uporczywą odmowę powinno się traktować jako odruchową reakcję organizmu, na którą najlepszą reakcją są częste wytrwałe i żarliwe delikatne napomnienia, a jeśli te nie pomagają, trzeba go zostawić w spokoju i zaczekać, aż się uspokoi. Dr Combe uspokajał Alberta, że „moralne organy” mózgu Bertiego są tak dobrze rozwinięte, że nie należy się obawiać, że będzie udawał niezrozumienie czy brak zdolności, żeby tylko uciec od nauki. Wręcz przeciwnie, wydaje się, że Bertie będzie uważał jakiekolwiek kłamstwo za całkowicie poniżej jego godności ${ }^{67}$.

${ }^{62}$ Sarah, Lady Lyttelton to W. H. Lyttelton, październik 1847, Correspondence of Sarah Spencer, Lady Lyttelton, s. 372.

${ }^{63}$ Queen Victoria to Leopold, king of Belgians, 20 IX 1842, Letters, t. 1, s. 549.

${ }^{64}$ Nt. popularności frenologii w wiktoriańskiej Anglii zob. T. M. Parssinen, Popular Science and Society: The Phrenology Movement in Early Victorian Britain, "Journal of Social History" vol. 8, No 1 (Autumn 1974), $1-20$.

${ }^{65}$ Andrew Combe został mianowany w 1838 r. lekarzem królowej w Szkocji. Był autorem bardzo poczytnej The Management of Infancy, Physiological and Moral (1840).

${ }^{66}$ Prince Albert to George Combe, 29 X 1851, w: Ch. Gibbon, The Life of George Combe, 2 vols., London: Macmillan, 1878, t. 2, s. 298-299, 215.

${ }^{67}$ RA VIC/MAIN/M/14/107, George Combe to Sir James Clark, 22 VI 1850, RA VIC/MAIN/M/15/2, George Combe to Prince Albert, 21 X 1850, National Library of Scotland, MSS. 7437, Correspondence of Prince Albert with Dr George Combe, Dr George Combe's reports, cyt. za: Ch. Hibbert, Edward VII, s. 10. 
Odpowiedzią Stockmara na opinie frenologów i na problemy z Bertim było zalecenie systematycznego ćwiczenie mózgu. Pod opieką guwernantki, Panny Hildyard, sześcioletni Bertie miał realizować szczegółowo określony plan zajęć. Od godziny 8 do 18, cały czas był rozpisany na różne lekcje i zajęcia, i np. w styczniu 1848 r., Bertie miał następujący program dnia:

Od 8:20-9:00 arytmetyka, dyktando, pisanie

11:30-12:30 francuski

13:00-13:55 niemiecki

16:00-17:00 czytanie, geografia, pisanie

17:00-18:00 taniec; w inne dni chronologia i historia, czytanie poezji

18:00 czytanie opowiadań; zabawa z mapami historycznymi lub gry planszowe ${ }^{68}$.

Opracowane przez Stockmara szczegółowe założenia, cele i metody wczesnego wychowania Bertiego nie przynosiły jednak oczekiwanych rezultatów i nauczyciele coraz częściej skarżyli się na brak zadowalających postępów u księcia. I nawet Lady Lyttleton zmuszona była przyznać, że pod wieloma względami jest on „bardzo trudnym uczniem”, a poza tym wcale nie jest rozwinięty lepiej niż dzieci w jego wieku ${ }^{69}$.

Pierwszym tutorem księcia został trzydziestoletni Henry Birch, wykształcony w Cambridge, master z Eton, najbardziej elitarnej prywatnej szkoły dla chłopców. W kwietniu 1849 r. na okres 3 lat, wyznaczono go na przełożonego wszystkich nauczycieli księcia, $\mathrm{z}$ roczną pensją w wysokości 800 funtów.

Jego zadaniem było ścisłe przestrzeganie zasad opisanych w programie edukacji przygotowanym przez Stockmara i zaakceptowanym przez Alberta oraz przygotowywanie regularnych sprawozdań z postępów Bertiego. Zaczynali o 8 i kończyli o 16, a gdy Bertie ukończył 9 lat o 16:30. Każdy dzień podzielony był na pięć godzinnych lub półgodzinnych lekcji. Birch uczył arytmetyki, geografii i angielskiego, a inni nauczyciele religii, niemieckiego, francuskiego, kaligrafii, rysunku i muzyki. Bertie miał krótsze wakacje niż inni chłopcy w jego wieku uczęszczający do prywatnych szkół.

Bertiemu nie podobał się wcale narzucony, przeładowany programem system, który oznaczał pięciogodzinne lekcje pięć dni w tygodniu. Birch raportował, że Bertie był bardzo niepostuszny, zachowywat się bezczelnie $w$ stosunku do nauczycieli, i niechętnie podporzadkowywat się dawat się dyscyplinie. Byt tez niezwykle samolubny, $i$ nie byt w stanie kontynuować żadnej gry czy zabawy nawet przez kilka minut, lub podjać próbe zrobienia czegoś nowego lub trudnego, bez utraty panowania nad soba. Nienawidził, gdy ktoś sobie z niego żartuje, ale mimo jego drażliwości śmiałem się z niego [...] i traktowatem tak, jak byłby traktowany $w$ każdej angielskiej prywatnej szkole, i tak jak ja sam bytem traktowany ${ }^{70}$.

\footnotetext{
${ }^{68}$ RA VIC/MAIN/M/12/66, Miss Hildyard's Table of Time for the Children; styczeń 1848.

${ }_{69}$ RA VIC/MAIN/M/13/89, Lady Lyttleton to Queen Victoria, 3 IX 1847.

${ }^{70}$ Gibbs Papers, Ph. Magnus, King Edward, s. 7.
} 
Ostatecznie Birch zasugerował, że krnąbrność Bertiego musi się spotkać ze zdecydowaną reakcją i być karana z surowością. W odpowiedzi Albert zdecydował się na kary cielesne, przede wszystkim chłostę, które miały „wspaniały efekt”71.

Birch uważał, że Bertie powinien mieć więcej kontaktu ze swoimi rówieśnikami. Praktycznie, poza codziennymi, kilkuminutowymi spotkaniami z rodzicami, nie widywał nikogo poza swoimi nauczycielami ${ }^{72}$. Niestety, opinia Alberta i Stockmara była inna. Poza tym, Albert przestał ufać Birch'owi i uznał, że jego odmowa udziału w prezbiteriańskich nabożeństwach podczas pobytu w Balmoral oznacza brak lojalności ${ }^{73}$. Mimo chęci pozostania na stanowisku, Birch po trzech latach, w lutym 1852 r., pożegnał się z posadą i przyjął święcenia kapłańskie ${ }^{74}$. Bertie, który zdążył przywiązać się do tutora był prawdziwie zasmucony ${ }^{75}$ i korespondował z nim przez jakiś czas, opisując najważniejsze wydarzenia ${ }^{76}$. Ale nie obeszło to wcale Alberta, który najprawdopodobniej zapomniał już o swoich traumatycznych przeżyciach związanych z rozstaniem $\mathrm{z}$ ulubionym tutorem, Christophem Florschützem ${ }^{77}$.

Na odejściu Birch podsumował swoje spostrzeżenia dotyczące Bertiego. Przyznawał, że jego postępy w pisaniu i ortografii były kiepskie, ale niewielu angielskich chłopców znało tak dobrze niemiecki i francuski. Psycholog dziecięcy XXI w. z pewnością zdiagnozowałby u Bertiego nadpobudliwość, dysleksję ${ }^{78}$ i być może dyspraksję (obniżone zdolności manualne), która powodowała, że pisanie było dla niego mozolną czynnością ${ }^{79}$. Ma bardzo wyczulone postrzeganie tego co dobre i co złe, bardzo dobra pamięć, i wyjątkowy dar obserwacji, ale jego problemy w dużym stopniu wynikają z tego, że nie ma on kontaktu z rówieśnikami i sam jest centrum, wokół którego wszystko się obraca, jednak, podsumowuje Birch, wszystko wskazuje na to, że z księcia Walii ostatecznie wyrośnie dobry, a w mojej skromnej opinii, wielki człowiek ${ }^{80}$.

Nowym tutorem dziewięcioletniego Bertiego i jego sześcioletniego brata, Alfreda (nazywanego w rodzinie Affie) został wykształcony w Cambridge prawnik ze średniej

${ }^{71}$ Royal College of Physicians, GB 0113 MS-CLARJ, Sir James Clark Diary, 24 VI 1849; RA VIC/ MAIN/15/19, H. Birch to Ch. F. Stockmar, 24 XI 1850.

72 RA VIC/MAIN/M/14/49, H. Birch's Private Thoughts, 1 XII 1849.

${ }^{73}$ Benjamin Disraeli to Lady Londonderry, 10 X 1851, Londonderry Papers, cyt. w Ch. Hibbert, King Edward, s. 11.

${ }^{74}$ Prince Albert to Prince William of Prussia, 27 I 1852, The Letters of the Prince Consort, 1831-1861, ed. Kurt Jagow, London: John Murray, 1938, s. 182. Wbrew powszechnej opinii Birch został wyrzucony z posady przez Alberta, mimo, że chciał pozostać na stanowisku. J. Ridley, Bertie, s. 22-4.

${ }^{75}$ Lady Canning, jedna $\mathrm{z}$ dam dworu królowej, pisała, że zachowanie Bertiego, który na wiadomość o odejściu Bircha przesyłał mu drobne prezenty i wiadomości, było „niezmiernie wzruszające”. S. Weintraub, The Importance of Being Edward, s. 17.

${ }^{76}$ The Education of a Prince. Extracts from the Diaries of Frederick Waymouth Gibbs, 1851-1856, "The Cornhill Magazine" vol. 165, no 986 (Spring 1951), 105-119, s. 106.

77 Zob. M. Misztal, Królowa Wiktoria, s. 90-91.

78 Por. S. Weintraub, The Importance of Being Edward, s. 3.

79 RA VIC/MAIN/M/14/37, Prince Albert's memorandum, Education of the Prince of Wales, 12 IV 1849 ; RA VIC/MAIN/Z/444/68, Tarver to Prince Albert, 9 III 1848, Ridley, Bertie, s. 21.

${ }^{80}$ RA VIC/MAIN/M/15/107, H. Birch's Memorandum, 25 II 1852. 
klasy, Frederick Waymouth Gibbs, którego spojrzenie na edukację było bardzo podobne do Stockmara i Alberta. Za swoją pracę miał dostawać roczne uposażenie w wysokości aż 1000 funtów. Jego opiekun i patron, Sir James Stephen z Cambridge, pisał, że oschły w rzeczywistości Gibbs nie ma sobie równych, jeżeli chodzi o umiłowanie ,prawdy, honoru, powagi i czystości”, jest odważny i energiczny, ufny we własne siły i czasem uparty, co może być odbierane jako szorstkość i apodyktyczność, ale nigdy nie jest posępny lub drażliwy, tylko życzliwy i o łagodnym charakterze ${ }^{81}$.

Po wstąpieniu na tron Edward VII nakazał zniszczenie większości dokumentów związanych z jego edukacją ${ }^{82}$, ale Gibbs prowadził dziennik, w którym zapisywał codzienne spostrzeżenia dotyczące księcia Walii ${ }^{83}$. Lekcje zostały wydłużone do sześciu godzinnych lekcji dziennie przez sześć dni w tygodniu. Zajęcia zaczynały się o 8 rano, a kończyły o 19 wieczorem. Przerwy między poszczególnymi lekcjami wypełnione były wymagającymi ćwiczeniami fizycznymi, które niejednokrotnie bardziej przypominały reżim w obozie karnym, tak aby upewnić się, że wieczorem książęta będą porządnie zmęczeni. „Lżejsza” lektura, a za taką Gibbs uważał nawet powieści Waltera Scotta, została zakazana.

Jednak Gibbs wprowadził w kształceniu Bertiego jedną ważną innowację, mianowicie przekonał Alberta, by zezwolił na kontakty książąt z uczniami z arystokratycznych rodzin pobliskiego Eton. Ale chociaż Bertie brał teraz udział w spotkaniach klubu dyskusyjnego w Eton, nie oznaczało to wcale, że rzeczywistości mógł kontaktować się swobodnie z chłopcami w swoim wieku. Rewizyty dokładnie wyselekcjonowanych uczniów z Eton w Windsorze również nie były wielkim sukcesem i rektor, Dr Edward Hawtrey, skarżył się, że Bertie „czerpie przyjemność z zadawania bólu innym”, co zresztą było zauważane i komentowane też przez inne osoby z otoczenia księcia ${ }^{84}$, i co Stockmar uznał za charakterystyczną cechę choroby umysłowej, która dotknęła Jerzego III. Podczas jednej z takich wizyt w 1854, Bertie spotkał Charlesa Carringtona, który miał się stać jego najbliższym przyjacielem do końca życia, jedynym do którego zwracał się po imieniu. Sam Carrington wspomina, że chociaż faworytem wszystkich był książę Alfred, on wolał Bertiego, który często pakował się w tarapaty, ale miał "tak bardzo życzliwe i wielkoduszne usposobienie i najczulsze serce z możliwych”. Jednocześnie Carringtom wspomina, że Bertie bał się bardzo ojca, który nieustannie go obserwował, a nawet śledził z ukrycia i wydawał się człowiekiem „,dumnym, nieśmiałym, pełnym rezerwy”, który nie potrafił zaprzyjaźnić się $\mathrm{z}$ dziećmi ${ }^{85}$.

81 The Education of a Prince, s. 105.

${ }^{82}$ RA GV/GG9/439, Viscount Esher to Frederick Ponsonby, 19 IV 194. Nt. niszczenia dokumentów przez Edwarda VII po dojściu do władzy, zob. Ridley, Bertie, s. 480-4; nt. cenzurowania dokumentów przed publikacją zob. Yvonne Ward, Censoring Queen Victoria.

${ }^{83}$ Obszerne wyjątki z dziennika zostały opublikowane pt. The Education of a Prince.

842 III 1853, The Education of a Prince, s. 117. Dziadek Bertiego ze strony matki, książę Kent, również znany był z okrucieństwa, które zniweczyło jego karierę w armii. Zob. M. Misztal. Królowa Wiktoria, s. 11-12.

${ }^{85}$ Bodleian Library, MSS Film 1120, Papers of Charles Robert Wynn-Carrington, marquess of Lincolnshire, „King Edward VII as I knew Him for 55 years”. 
Wyniki osiągane przez Gibbsa nie były zadowalające. Z lekcji na lekcje Bertie był coraz bardziej zuchwały i nieposłuszny, odmawiając uczenia się czegokolwiek lub wykonywania poleceń. Dziennik Gibbsa roi się od uwag typu: był „ciągle poddenerwowany”, „,pobudzony i nieposłuszny”, „gwałtowny”, „,niegrzeczny”, ,,robił głupie miny”, „obrzucał mnie wyzwiskami”, „nie mógł się skupić”, „rzucał ołówkiem po pokoju:, „kopał i przewracał stołki:, „,uderzył księcia Alfreda”, „kłócił się i bił Alfreda”, „,ciągnął Alfreda za włosy wymachując nożem do korespondencji”, „rzucał we mnie kamieniami”, „rzucał we mnie błotem”. Kiedy w końcu Bertie posunął się do przemocy fizycznej, uderzając Gibbsa w napadzie gniewu kijem, ten poskarżył się Albertowi. Odpowiedzią było, że Gibbs powinien był trzepnąć Bertiego po uszach lub zbić tym samym kijem „porządnie” po łapach. Ostatecznie karą było zamknięcie księcia w pokoju ${ }^{86}$.

Wiktoria była zachwycona takim traktowaniem Bertiego przez Gibbsa, którego uważała za „prawdziwy skarb” i informowała wuja Leopolda, że od jego przybycia nasz biedny dziwaczny chtopiec bardzo się poprawit ${ }^{87}$. W rozmowie z Gibbsem przyznawała, że przebywanie w przedszkolu z Vicky, która była bardzo inteligentna i sprytna, mogło wpłynąć negatywnie na jego psychikę i do dzisiaj Bertie czasem zwiesza głowę i patrzy na swoje stopy, a co dzień lub dwa miewa napady nerwowej niepohamowanej złości, a gdy jest bardzo zmęczony często traci panowanie nad sobą ${ }^{88}$.

Ani Albert, ani Stockmar nie zważali wcale na uwagi innych nauczycieli krytykujące zachowanie Gibbsa, np. nauczyciel języka niemieckiego, Dr Becker, w swoim raporcie pisał, że wybuchy gniewu są spowodowane po prostu przepracowaniem chłopca ${ }^{89}$. Jedyną reakcja na takie uwagi było zachęcanie Gibbsa do eksperymentowania z nowymi metodami $^{90}$ i polecenie Alberta, że Bertie ma kontynuować lekcje nawet podczas wakacyjnych wypraw królewskiej rodziny do szkockiego Balmoral, co nawet Gibbs uznał za przesadę ${ }^{91}$. Ostatecznie Stockmar wydaje się stracił wszelką nadzieje, że Bertie kiedykolwiek spełni pokładane w nim nadzieje. Gibbsowi powiedział, że Bertie jest „ciężkim przypadkiem" ${ }^{92}$, „przesadzoną kopią jego matki" ${ }^{93}$ i jeżeli Gibbs uzna, że nie jest w stanie nic już zrobić, niech przynajmniej zajmie się młodszym księciem, Alfredem ${ }^{94}$.

Po kilku latach obserwacji, Gibbs uważał, że w zachowaniu Bertiego widać „ciągły konflikt pomiędzy impulsem i zasadami”. Przeważnie „,pod wpływem impulsu” jest niegrzeczny i nieuprzejmy, kpi i drażni się z innymi i w konsekwencji jego swawolny i żartobliwy ton jest odbierany jako ,nieokrzesanie i gburowatość”. Gibbs uważa, że Bertie

8618 II 1852, The Education of a Prince, s. 111.

${ }^{87}$ RA VIC/MAIN/Y/97/23, Queen Victoria to Leopold, king of Belgians, 29 VI 1852. Por. 22 IV 1852, The Education of a Prince, s. 114-115.

8816 I 1852, The Education of a Prince, s. 107.

${ }^{89}$ Becker to Prince Albert, 19 I 1852, Ph. Magnus, King Edward, s. 10-11.

9031 III 1852, The Education of a Prince, s. 114.

9120 IX 1852, The Education of a Prince, s. 116.

9228 I 1852, The Education of a Prince, s. 107.

9314 II 1852, The Education of a Prince, s. 110.

9431 III 1852, The Education of a Prince, s. 114. 
zadaje sobie sprawę z tego, że nie jest tak życzliwy jak powinien, czy nawet chciałby być, dlatego w każdym słowie widzi naganę i nawet dobre rady odbiera w ten sposób. Z drugiej strony, kontynuuje Gibbs, jest ,poczucie obowiązku” związane ściśle z pragnieniem aprobaty ze strony ojca i matki i z poczuciem satysfakcji płynącej z dobrego zachowania. Co prawda Bertie ma duże problemy z koncentracją a „myślenie wymaga od niego wysiłku, czasami bolesnego wysiłku", ale pomocne tu może być rozwijanie jego upodobania do zabawy i rozrywki, które wymagają wytrwałości i namysłu. W charakterze Bertiego zwracają uwagę takie cechy, jak ,wyobraźnia, wrażliwość na piękno i poczucie humoru". Ogólnie rzecz biorąc, kończy swój raport Gibbs,

należy pamiętać, że jak na jego wiek jest dziecinny, i musi przez jakiś czas być uznany za opóźnionego umysłowo. W swoich najlepszych momentach widać u niego prawdziwą wolę uczenia się [...] Nawet jeżeli te wysiłki nie są długotrwałe, pokazują wystarczająco dużo uśpionej siły, aby móc mieć nadzieję, że kiedy osiągnie wiek, w którym zda sobie sprawę z odpowiedzialności swojej pozycji, z poczucia obowiązku zbierze w sobie siły do większej pracy, a jeżeli w międzyczasie uda się wpoić mu tę podstawową wiedzę, którą można posiąść jedynie w dzieciństwie, jego wrodzony spryt i zdrowy rozsądek pozwoli mu pojąć i w odpowiedni sposób wywiązywać się z obowiązków, do których zostanie powołany ${ }^{95}$.

W 1856 r. rodzice pogodzili się z myślą, że książkowa edukacja Bertiego nie pasuje do jego temperamentu i poziomu inteligencji, i zdecydowali, że dobrą alternatywą mogą być podróże. Jesienią wysłali go na pieszą wycieczkę po Devonie, ale chociaż Bertie podróżował incognito, jako baron Renfrew, sekret został odkryty i po drodze witały go tłumy demonstrujące swoją lojalność. Nie spodobało się to rodzicom i wycieczka została natychmiast zakończona. W następnym roku Bertie wyjechał $\mathrm{w}$ pierwszą, czteromiesięczną, podróż po Europie, odwiedzając Bonn, gdzie miał studiować niemiecki język i literaturę, a potem Szwajcarię.

W 1856 r. dorastający książę otrzymał roczne kieszonkowe w wysokości 100 funtów i pozwolenie na wybór własnych ubrań. Jednocześnie, zaniepokojona podejściem syna do strojenia się Wiktoria, wyniosłym i pełnym namaszczenia językiem, tłumaczyła mu jakie miejsce w jego życiu powinny zajmować stroje. Nie chcemy kontrolować twoich własnych gustów i upodobań, które wedtug nas powinieneś zaspokajać i rozwijać i zaraz dodawała, ale spodziewamy się, że nigdy nie będziesz nosić niczego ekstrawaganckiego, nie dlatego, że nam się nie podoba, ale dlatego, że dowodziłoby braku szacunku dla samego siebie i przeczyło dobrym manierom, prowadzac - tak jak to czesto bywa u innych - do zobojętnienia na rzeczy moralnie złe ${ }^{96}$. Ostrzeżenia matki na nic się zdały i Albert skarżył się w liście do Vicky, że Bertie interesuje się tylko $i$ wyłacznie swoimi strojami, i nawet w czasie polowania bardziej zajmuja go spodnie niż zwierzyna ${ }^{97}$, a Wiktoria skar-

\footnotetext{
95 Gibb's Memorandum for the Queen, maj 1854, The Education of a Prince, s. 118-119.

${ }^{96}$ Queen Victoria to the Prince of Wales, 26 X 1857, V. Esher, The Influence of King Edward and Essays on Other Subjects, London 1915, s. 10.

97 Prince Albert to Victoria, the Princess Royal, 17 XI 1858, E. Caesar, The English Empress: A Study in the Relations between Queen Victoria and her Eldest Daughter, tr. E. M. Hodgson, London 1957, s. 50.
} 
żyła się córce, że zasmuca mnie on bardzo. Jest taki leniwy i słaby ${ }^{98}$. Wiktoria podświadomie zdawała sobie prawdopodobnie sprawę, że Bertie jest jakby jej karykaturą ${ }^{99}$. Odziedziczył po niej radość życia, wybuchowy temperament i niechęć do nauki. Ale, niestety, nadal nie przypominał wcale swojego ojca.

W kwietniu 1858 r., ku zaskoczeniu rodziców, Bertie dobrze zdał egzamin z religii i przystąpił do anglikańskiej konfirmacji. W nagrodę dostał pozwolenie na dwutygodniowe wakacje w Irlandii, ale zaraz potem Albert zdecydował, że powinien zostać „odizolowany od świata” i przygotowywać się do egzaminu na akademię wojskową. Trzech doświadczonych, bywałych, oficerów miało dbać o doszlifowanie jego manier. Albert wypunktował im, że książę ma być uczony odpowiedniego sposobu poruszania się, dbałości o wygląd i ogłady towarzyskiej; nie wolno mu się garbić, ani trzymać rąk w kieszeniach, ma być punktualny, nie plotkować, ani grać w karty czy bilard.

W listopadzie 1858 r., w dzień siedemnastych urodzin, Bertie otrzymał dokument podpisany przez rodziców, w którym oświadczali mu, że zostaje „wyzwolony” spod opieki i kontroli rodzicielskiej. Przyznawali, że chociaż mógł myśleć, że jego edukacja była czasem zbyt surowa, robili wszystko dla jego dobra, chcąc wzmocnić jego umysł i przygotować do radzenia sobie z ,nieodpartym urokiem pochlebstw”, na które będzie ciągle narażony. Od teraz będzie sam podejmował decyzje, a rodzice nie będą mu niczego narzucać, choć zawsze będą gotowi udzielić mu rady, jeżeli tylko o nią poprosi. Rodzice nie omieszkali przypomnieć Bertiemu, że życie składa się z obowiąków, a prawdziwego chrześcijanina, prawdziwego żotnierza i prawdziwego dżentelmena poznaje sie po ich należytym, terminowym $i$ ochoczym wypetnianiu ${ }^{100}$.

Eksperyment edukacyjny opracowany z niezwykłą pieczołowitością i mający na celu wykształcenie idealnego następcy tronu, w sumie zakończył się całkowitym niepowodzeniem. Bertie nie tylko że nie stał się intelektualistą, ale testowany na nim sposób edukacji tak skutecznie zniechęcił go do uczenia się, a nawet czytania czegokolwiek, że powszechna była opinia, iż nie przeczytał dobrowolnie w życiu ani jednej książki ${ }^{101}$. Zakrawało na ironię, że to nie Bertie, ale wszyscy jego młodsi bracia, którym poświecono o wiele mniej uwagi, odziedziczyli w pewnym przynajmniej stopniu zainteresowania naukowe i temperament, którego tak bardzo pragnęli dla niego rodzice. Alfred interesował się geografią i przedmiotami ścisłymi, nad wiek rozwinięty, cierpiący na hemofilię Leopold, był miłośnikiem sztuki i dobrej literatury, a Artur był chłopcem o wyjątkowo miłym usposobieniu i szybko stał się ulubieńcem matki.

Eksperyment edukacyjny nie przyniósł też spodziewanych efektów, jeżeli chodzi o moralne kształcenie księcia. Do końca życia królowa Wiktoria uważała, że śmierć jej ukochanego Alberta została jeżeli nie spowodowana, to przyspieszona przez skandal wy-

98 Queen Victoria to Victoria, the Crown Princess, 8 marzec 1858, Dearest Child, s. 73.

99 Queen Victoria to Victoria, the Crpwn Princess, 27 kwiecień 1859, Dearest Child, s. 187.

100 Queen Victoria and Prince Albert to The Prince of Wales, 9 XI 1858, V. Esher, op. cit., s. 13-15. Por. Ch. Greville, The Greville Memoirs. A Journal of the Reigns of King George IV, King William IV, and Queen Victoria, ed. Henry Reeve, London: Longmans, Green and Co, 1898, 8: 217, 4 XI 1858; St Aubyn, s. 41.

${ }^{101}$ Ch. Hibbert, op. cit., Palgrave Macmillan, s. 201. 
wołany przez romans osiemnastoletniego Bertiego z aktoreczką Nellie Clifden ${ }^{102}$, a niezmienne upodobanie księcia Walii i potem króla Edwarda VII do romansowania było powszechnie znane i.... zapewniło mu przydomek Pieszczoszek ${ }^{103}$. Ale ani nadmierne umiłowanie płci pięknej, ani godziny i fortuny spędzane na grze w kości, nie przeszkodziły ostatecznie we wzorowym wykonywaniu przez króla Edwarda VII monarszych obowiązków.

\section{Bibliografia}

Źródła archiwalne:

Royal Archives, Round Tower, Windsor Castle

RA VIC/MAIN/M/3/6

RA VIC/MAIN/M/12/14, 20, 44, 46, 55, 66

RA VIC/MAIN/M/13/45, 46, 51, 68, 87, 89

RA VIC/MAIN/M/14/37, 49, 107

RA VIC/MAIN/M/15/2, 19, 107

RA VIC/MAIN/Y/97/23

RA VIC/MAIN/Y/99/23

RA VIC/MAIN/Z/141/94

RA VIC/MAIN/Y/148/1

RA VIC/MAIN/Y/153/9

RA VIC/MAIN/Y/184/2, 12, 16, 18

RA VIC/MAIN/Y/198/140

RA VIC/MAIN/Y/198/181

RA VIC/MAIN/Z/442/43

RA VIC/MAIN/Z/444/68

RA GV/GG9/439

RA VIC/MAIN/QVJ (W). Queen Victoria's Journal (Princess Beatrice's copies). On line www. queenvictoriasjournals.org [Dostęp: 1206 2017]

\section{Źródła drukowane}

Bagehot W., The English Constitution, London 1867.

Bilz F. E., Nowe lecznictwo przyrodne, Lipsk 1903.

Bunsen S. B., King Edward VII, London: Macmillan 1925.

Caesar E., The English Empress: A Study in the Relations between Queen Victoria and her Eldest Daughter, tr. E. M. Hodgson, London 1957.

Combe A., The Management of Infancy, Physiological and Moral, London 1840.

102 RA VIC/MAIN/Z/141/94, Prince Albert to the Prince of Wales, 16 XI 1861; Queen Victoria to Victoria, the Crown Princess, 12 XI 1862, Dearest Mama, s. 132.

${ }_{103}$ Henry James to Oliver Wendell Holmes, Jr, January 1901; L. Edel, Henry James: The Master: 1901-1916, New York 1972. 
Correspondence of Sarah Spencer, Lady Lyttelton, 1787-1870, ed. Mrs. Hugh Wyndham, London 1912.

Crabites, P., Victoria's Guardian Angel: A Study of Baron Stockmar, London 1937.

Dearest Child: Letters Between Queen Victoria and the Princess Royal,1858-61, oprac. R. Fulford, Londyn 1964.

Dearest Mama: Letters Between Queen Victoria and the Crown Princess of Prussia, 1861-64, ed. R. Fulford, London 1968.

Edel L., Henry James: The Master: 1901-1916, New York 1972.

The Education of a Prince. Extracts from the Diaries of Frederick Waymouth Gibbs, 1851-1856, "The Cornhill Magazine" vol. 165, no 986 (Spring 1951), 105-119.

Education of the Royal Infants "Punch, or the London Charivari" IV (1843), s. 232.

Esher Lord The Influence of King Edward, London: John Murray 1915.

The Flogging of a Prince, „Cambridge Chronicle” vol. VIII no 21, 21 V 1853, s 3.

Gibbon Ch., The Life of George Combe, 2 vols., London: Macmillan, 1878.

Gordon P., Lawton D., Royal Education. Past, Present and Future, revised edn, London: Frank Cass, 2003.

Greville Ch., The Greville Memoirs, red. Lytton Strachey i Roger Fulford, 8 t., London, 1938.

Grey Ch., The Early Years of His Royal Highness The Prince Consort. Compiled under the Direction of Her Majesty the Queen, New York 1867.

Hibbert Ch., Edward VII. The Last Victorian King, London 2007.

Hibbert Ch., Queen Victoria. A Personal History, London 2000.

James R. C., Albert, Prince Consort, London 1983.

Lady Lyttelton's Correspondence, 1787-1870, ed. Mrs Hugh Wyndham, London 1912.

Letters of Queen Victoria: A Selection from Her Majesty's Correspondence, ed. Arthur Christopher Benson and Viscount Esher, 3 vols., London 1907.

The Letters of the Prince Consort, 1831-1861, ed. Kurt Jagow, London: John Murray, 1938.

Locke J., Some Thoughts Concerning Education. Vol. XXXVII, Part 1. The Harvard Classics. New York: P.F. Collier \& Son, 1909-14. Online www.bartleby.com/37/1/, par. 1 (Dostęp 22 IX 2015).

Magnus Ph., King Edward the Seventh, London 1964.

Martin Th., Life of H.R.H. the Prince Consort, 5 vols., London 1875-1880.

Meyer J., E'Education des Princes en Europe du XVe au XIXe Siecle, Perrin 2004.

Middlemas K., Edward VII, London: Weidenfeld and Nicolson, 1972.

Misztal M., Królowa Wiktoria, Ossolineum 2002.

Misztal M., Królowej Wiktorii spojrzenie na macierzyństwo [w:] Człowiek w teatrze świata, red. B. Popiołek. Kraków 2010, s. 53-68.

Mitchell L. G., Lord Melbourne, 1779-1848, Oxford 1997.

Murder of six children by their mother, "The Sidney Morning Herald" 12 IX 1954, s. 2, kolumna a.

Nawrot-Borowska M., Mamki - najemne karmicielki w świetle literatury poradnikowej z drugiej połowy XIX i poczattu XX wieku, „Biuletyn Historii Wychowania” 31 (2014), s. 85-112.

Pakula H., An Uncommon Woman. The Empress Frederick. Daughter of Queen Victoria, Wife of the Crown Prince of Prussia, Mother of Kaiser Wilhelm, London 1995.

Parssinen T. M., Popular Science and Society: The Phrenology Movement in Early Victorian Britain, "Journal of Social History", vol. 8, No 1 (Autumn 1974), 1-20.

Queen Victoria's Journal. On line www.queenvictoriasjournals.org [Dostęp: 1210 2015]

Raniszewska-Wyrwa A., Johna Locke'a koncepcja wychowania moralnego, „Biuletyn Historii Wychowania" 31 (2014), s. 161-175.

Ridley J., Bertie. A Life of Edward VII, London 2012.

St. Aubyn G., Edward VII. Prince and King, London 1979. 
Stockmar E. A., Denkwürdigkeiten aus den Papieren des Freiherrn Christian Friedrich v. Stockmar, Braunschweig 1872.

Thompson D., Queen Victoria. A Woman on The Throne, London 2001, s. 44.

Trial of a Woman for the Murder of Her Six Children - Plea of Insanity, "The New York Times" 25 VIII 1854.

Tucker N., Swiss Cottage, Osborne House, Isle of Wight, „History Today” vol 40, no 9 (September 1990), s. 62-63.

Vallone L., Becoming Victoria, London 2001.

Ward Y., Censoring Queen Victoria. How Two Gentlemen Edited a Queen and Created an Icon, London 2014.

Weintraub S., Albert. Uncrowned King, London 1997.

Weintraub S., The Importance of Being Edward. King in Waiting, 1841-1901, London 2000. 